2009

\title{
Using Classroom Resources Wisely with Accelerated Reader
}

\author{
Carolyn Hohman \\ Cedarville University
}

Follow this and additional works at: http://digitalcommons.cedarville.edu/education theses

Part of the Education Commons

\section{Recommended Citation}

Hohman, Carolyn, "Using Classroom Resources Wisely with Accelerated Reader" (2009). Master of Education Research Theses. 20.

http://digitalcommons.cedarville.edu/education_theses/20

This Thesis is brought to you for free and open access by 


\section{USING CLASSROOM RESOURCES WISELY WITH ACCELERATED READER}

A thesis project submitted in partial fulfillment of the requirements for the degree of Masters of Education

By

Carolyn S. Hohman

B.A. Elementary Education, Cedarville University, 1996

2009

Cedarville University 
SCHOOL OF GRADUATE STUDIES

December 1, 2009

I HEREBY RECOMMEND THAT THE THESIS PREPARED UNDER MY SUPERVISION BY Carolyn Sue Hohman ENTITLED Using Classroom Resources Wisely With Accelerated Reader BE ACCEPTED IN PARTIAL FULFILLMENT OF THE REQUIREMENTS FOR THE DEGREE OF Master of Education.
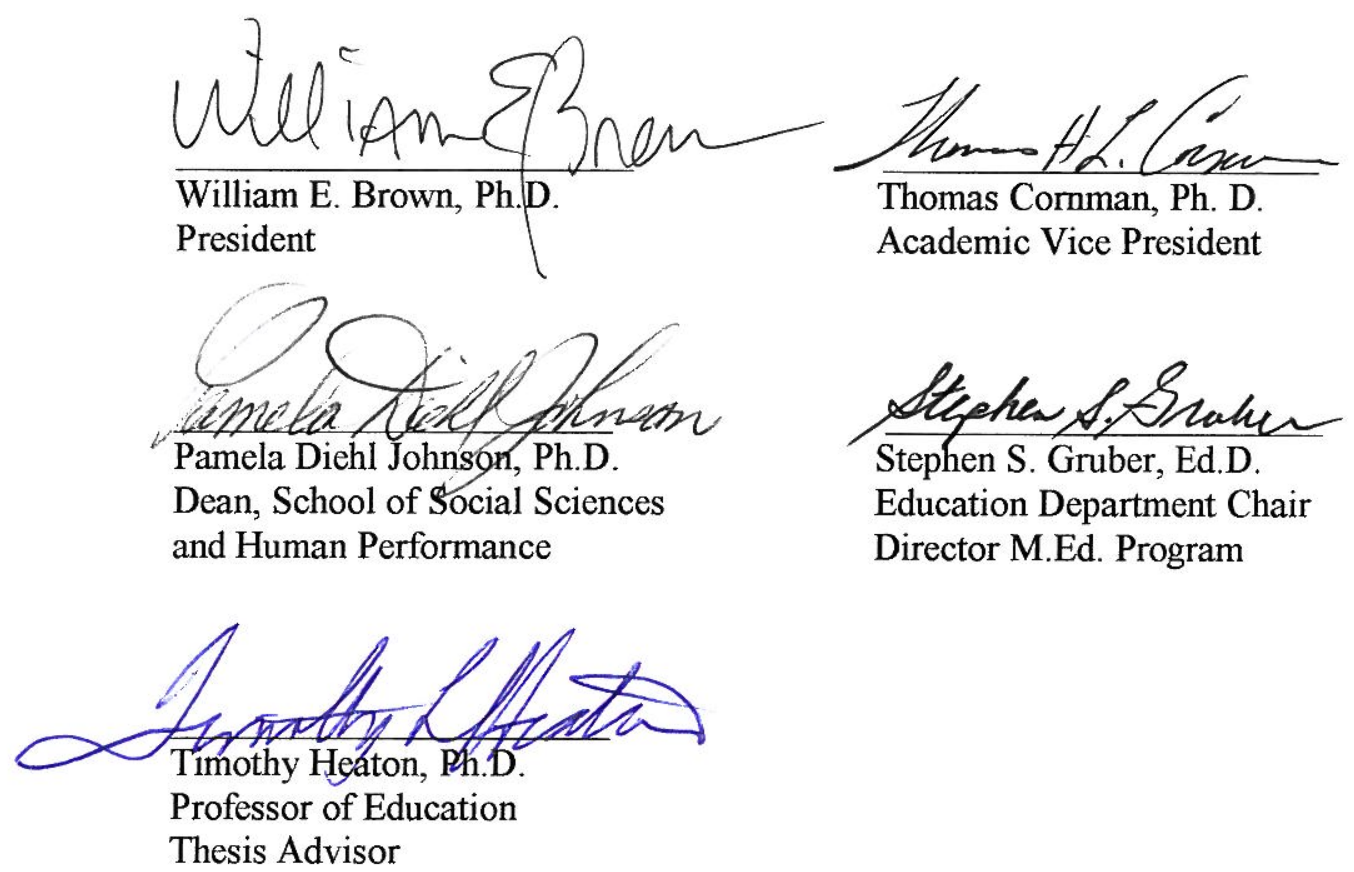


\begin{abstract}
Hohman, Carolyn S. M.Ed., Education Department, Cedarville University, 2009. Using Classroom Resources Wisely Using Accelerated Reader.
\end{abstract}

This thesis project consists of locating and creating teacher-made Accelerated Reader quizzes from a collection of trade books in an elementary classroom library. This collection was not being well utilized by students because the school did not provide a computerized Accelerated Reader Reading Practice Quiz for these titles. The goal is for the students to enjoy this collection of various leveled trade books while at the same time reaping the classroom and school-wide benefits of reading and comprehending Accelerated Reader books. 


\section{TABLE OF CONTENTS}

CHAPTER I: Introduction $\ldots \ldots \ldots \ldots \ldots \ldots \ldots \ldots \ldots \ldots \ldots$

Introduction to the Project $\ldots \ldots \ldots \ldots \ldots \ldots \ldots \ldots \ldots \ldots$

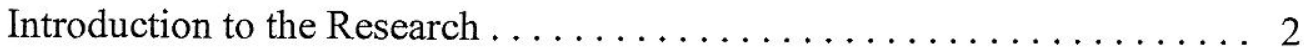

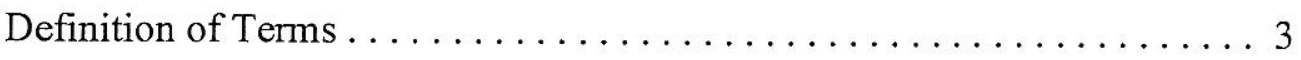

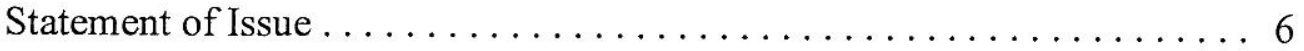

Scope of the Study and Delimitations $\ldots \ldots \ldots \ldots \ldots \ldots \ldots \ldots$

Significance of the Project $\ldots \ldots \ldots \ldots \ldots \ldots \ldots \ldots$

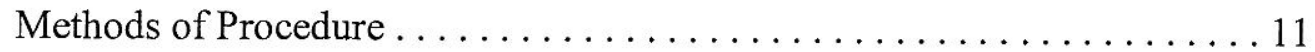

CHAPTER II: Plenary Literature Review $\ldots \ldots \ldots \ldots \ldots \ldots \ldots \ldots \ldots \ldots$

Overview of Accelerated Reader . . . . . . . . . . . . . . . . 13

Related Research and the Benefits of Accelerated Reader . . . . . . . . 15

Overcoming Limitations and Barriers of Accelerated Reader . . . . . . . 24

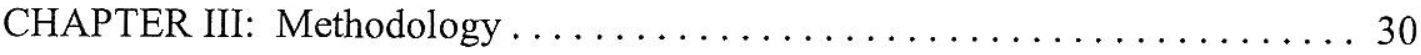

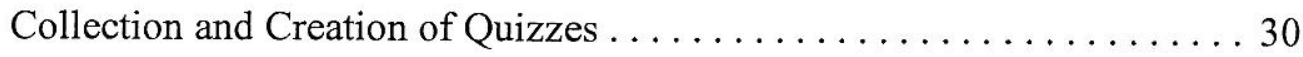

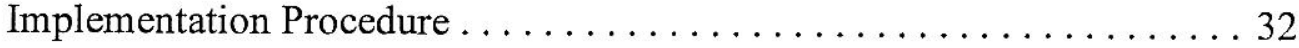

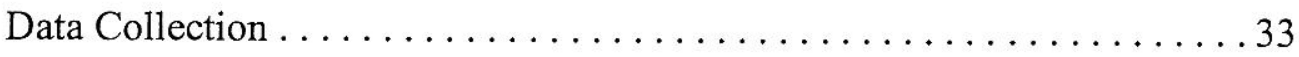

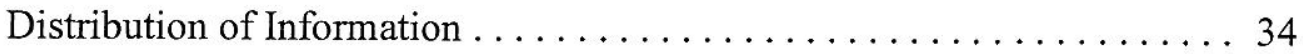

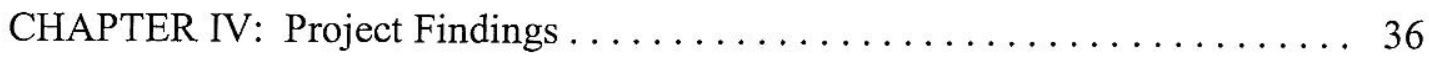

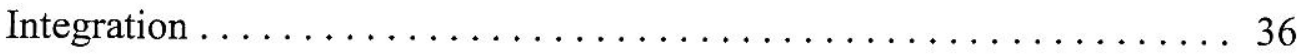

Key Themes .............................. 39 
CHAPTER V: Discussion and Implications $\ldots \ldots \ldots \ldots \ldots \ldots \ldots \ldots \ldots$

Biblical Integration $\ldots \ldots \ldots \ldots \ldots \ldots \ldots \ldots \ldots \ldots \ldots \ldots \ldots \ldots \ldots \ldots \ldots$

Strengths of the Project ................... 46

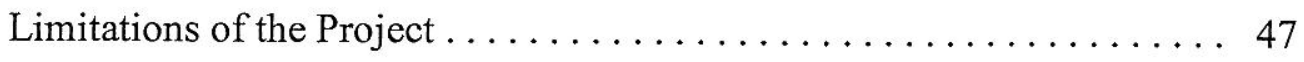

Suggestions for the Future $\ldots \ldots \ldots \ldots \ldots \ldots \ldots \ldots \ldots$

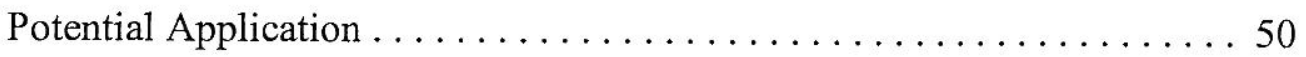

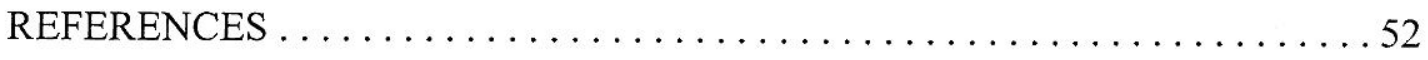

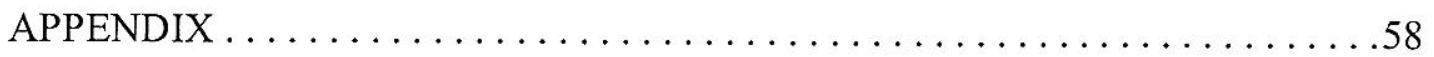

Appendix A: Samples of Self-Created Accelerated Reader Quizzes. . . . . 59 


\section{Chapter 1}

Introduction

\section{Introduction to the Project}

Reading is a staple in school and in life. Millions of dollars are spent each year on reading programs for schools all over the country. Because reading is highly cognitive and complex in its nature (Rapp \& van den Brock, 2005), the complexity of choosing and implementing components for a reading program exists as well. For many years, Maplewood Intermediate School has chosen and implemented the Accelerated Reader program from Renaissance Learning as a supplement to their standard basal reading curriculum. Accelerated Reader's purpose is to motivate students to read higherlevel books for their reading level and increase their silent reading time (Florida Center for Reading Research, 2006).

Maplewood Intermediate's school library provides its students and staff with thousands of Accelerated Reader books and corresponding computerized quizzes based on these trade books. However, it is convenient and often necessary to have as many Accelerated Reader books in individual classroom for ease of student access at any time during the school day. The purpose of this project is to use a third grade classroom's library resources more wisely by locating and creating teacher-made Accelerated Reader quizzes for the classroom books for which the school does not provide Accelerated Reader quizzes. The goal is to add to the classroom and school's Accelerated Reader program in order to promote greater student reading achievement and enjoyment. 


\section{Introduction to the Research}

In order for an academic program to be as effective as possible the following research suggests it must meet the students on their own various levels and offer motivation that leads to practice. First, students need literature on their reading level. Stahl and Heubach (2006) found that individual students need to have appropriately challenging books. Literature is needed that is not too easy nor too difficult but push students to a new level without frustrating them. A one size fits all approach will not be successful. Students need access to a varied level of books in the classroom (Pitcher et al., 2007).

Secondly, motivation is needed. When some students believe reading and the literature activities are unrewarding, too difficult, or of little interest to them, they can become non-readers (Strommen \& Mates, 2004). Students want to feel rewarded, interested, and appropriately challenged to feel motivated in their reading endeavors. Guthrie et al. (1999) found motivation to read is the "preeminent predictor" of recurring reading. If you are reading a book that does not interest you or is too difficult for you to

comprehend, you will begin to dread and turn away from reading because of your lack of motivation. From these studies, appropriate reading material combined with desire is necessary. Topping \& Paul (1999) summarize this by stating there is little enjoyment or motivation when there is not fluency and comprehension.

To achieve higher reading levels, students must also spend time reading. Krashen (2009) researched many previous reading studies and found the more students read the better they read. However, how much time do students actually spend reading on their own? A study by Kurth and Kurth (1987) found that first, third, and fifth graders 
participated in only 10 minutes of silent reading during their reading period. Personal reading time cannot be thought of as a luxury in the classroom.

One major goal of teachers is to develop students who enjoy reading and continue to be life-long readers (Pavonetti, Brimmer, \& Cipielewski, 2002). The Accelerated Reader program promises to help motivate students to become these life-long readers. The program states it will get students excited about their individual reading after they experience success with this program. This program is based on giving the student appropriate reading material, from real trade books, based on their ability and interests. It is a computerized reading program based on the principle that practice improves reading. Basically the procedure for using the Accelerated Reader program involves three simple steps: 1) the student selects and reads a trade book, 2) the student completes a short, multiple-choice, computerized reading comprehension quiz based on the book's information; 3) the quiz results are added to the program from which reports and data can be drawn for the student and the teacher (Renaissance Learning, 2009).

\section{Definition of Terms}

Accelerated Reader (AR) - This is a computer-based assessment for reading comprehension of trade books. Students read the text, take a quiz, and the program summarizes the results (Vollands, Topping, \& Evans, 1999).

Accelerated Reader Level or Reading Level- This is the level from which students select their AR books. This level will allow a student to be reading a book that is not too difficult or too easy for them. This level is based on the Zone of Proximal Development score from their STAR Quiz (STAR Program Manual, n.d.). 
Accelerated Reader Points -In the AR program, each book is worth a specified number of points depending on the length and difficulty of the text. Students earn all or some of these points according to their score on the Reading Practice Quiz (Vollands, Topping, \& Evans, 1999).

Adaptive Branching - This is a feature of the STAR Quizzes. The program weighs each student answer and adapts the next question to the appropriate level of difficulty (STAR Program Manual, n.d.).

Customized Reports - Accelerated Reader reports can be customized to include only the scores, percentages, date range, and students desired (Accelerated Reader Program Manual, n.d.).

Grade Equivalent (GE) - This indicates the normal grade placement of students who would achieve a given score on the STAR Quiz. Scores range from 0.0 to $12.9+$. The whole number indicates the grade level, and the tenths indicate the month of that grade level (STAR Program Manual, n.d.).

Leveled Literature or Leveled Books - Books that are on various reading levels of difficulty.

Marking Period Progress Report - This is one type of Accelerated Reader report. It displays the number of books read in a specified marking period, score received for each quiz, average book level, average scores, and points received (Accelerated Reader Program Manual, n.d.). Norm-Referenced Scores - This is a measure of a student's performance compared to other students' performance on the same quiz. Grade equivalencies from the STAR Quiz are norm-referenced scores (STAR Program Manual, n.d.). 
Parent Report - This is a printout sent home to parents that shows a student's STAR Quiz results from a particular Quizzing session. It includes easy-to-understand information and definitions so parents can track their student's progress (STAR Program Manual, n.d.).

Reading Practice Quizzes - This is a computerized quiz a student takes after reading a book that verifies whether a student has read and understood the book. The results are printed on a TOPS report (Accelerated Reader Program Manual, n.d.).

Renaissance Learning - This is the company that produces the STAR and Accelerated Reader program (Renaissance Learning, 2009).

Sustained Silent Reading Time - This is a period of time in the classroom when all students silently read a book they have self-selected.

STAR Quizzes - This is a computer-adaptive, norm-referenced Quiz for students that can be given up to five times per year. The results give information regarding student strengths and weakness, reading growth, and student readability levels. This program can be used in tandem with the Accelerated Reader program (STAR Program Manual, n.d.). Teacher-Made Quizzes - Quizzes for the AR program can be created and manually installed by the teacher. These quizzes are then available to students to use the same as the purchased Reading Practice Quizzes available through Renaissance Learning (Accelerated Reader Program Manual, n.d.).

TOPS Report - This report prints out immediately after a student takes a Reading Practice Quiz. It includes the name of the book read, the score and points earned, as well as cumulative information from the marking period and entire school year (Accelerated Reader Program Manual, n.d.). 
Zone of Proximal Development (ZPD) - This is a personal readability range from which students should be selecting books in order to experience optimum growth without experiencing frustration. The student's grade equivalent score on the STAR test determines this (STAR Program Manual, n.d.).

\section{Statement of Issue}

Teachers know that one of the best ways to improve student success in reading is simply to have students read more. Research supports this belief. Several studies have suggested a strong link between the student's amount of time spent reading and the student's reading achievement (Cummingham \& Stanovish, 1997; Guthrie, Wigfield, Metsala, \& Cox, 1999). From the results from these studies, it follows that students would benefit a great deal from having as much time as possible allotted to them for the purpose of personal reading.

Further studies show that students who read by personal choice earn higher grades in school (Sweet, Guthrie, \& Ng, 1998) and score higher on standardized tests (Gottfried, 1990). Therefore, these studies show students who willingly read by their own choice will excel more than those that do not. From this research, it seems personal reading time combined with personal motivation to read is key to a student's greater success in reading.

However, when students are given time to silently read a self-selected book during school hours, quality reading often does not occur. This is exactly what Kelley and Clausen-Grace (2006) found during their study of sustained silent reading time in classrooms. They found that even though students appeared to be reading, many were 
not engaged in the activity. One reason was because students were reading books that were not challenging enough or were too challenging for them. Another problem with silent reading time is that students often do not have any accountability for their reading performance during this time (Pilgreen, 2000), and teachers cannot track the students' understanding of their texts (Vollands, Topping, \& Evans, 1999).

From these studies, it seems for sustained silent reading time, students need a standard means of selecting appropriate books for their reading level. Students also need some accountability to help prevent the wasting of the quiet reading time. Also seen in these studies, teachers need a way of measuring the students' silent reading comprehension. The Accelerated Reader program offers a solution to these needs. It is a computer-assisted assessment program that provides students with parameters and accountability and provides teachers with feedback on student comprehension (Vollands, Topping, \& Evans, 1999). Giving students and teachers as much access as possible to what this program offers will help meet the needs of all involved.

\section{Scope of the Study and Delimitations}

This project was implemented at Shawnee Maplewood Intermediate School in Lima, Ohio. It is a suburban, public, intermediate school in northwestern Ohio that houses only third and fourth grade students. The school is over $90 \%$ Caucasian, with approximately $20 \%$ on the free and reduced lunch and breakfast programs, and with approximately $20 \%$ on Individualized Education Programs (IEPs).

In this project, teacher-made Accelerated Reader quizzes based on trade books were located and created specifically for a Maplewood Intermediate third grade 
classroom's library. These were quizzes from which Maplewood Intermediate has not purchased copyrighted Accelerated Reader Reading Practice Quizzes from Renaissance Learning (Renaissance Learning, 2009). These copyrighted quizzes were not purchased because the school only obtains the quizzes if the school library houses the specific books that correspond with those quizzes so as to benefit all the students in the building. It did not have these specific titles in its collection since these trade books were a part of a specific classroom library within the school. In order for the school to purchase these quizzes for these specific books, the school library would have to purchase a hard back copy of the book as well as the AR Reading Practice Quizzes from Renaissance Learning. The library funds were not available as this would have been a substantial expense for the purchase of 48 titles and quizzes.

This project was designed to specifically benefit a class of 27 third graders, but students in other classrooms within the school could benefit from it as well. Due to the widespread use of the Accelerated Reader program, the quizzes created from this project could also be useful to other teachers and students with access to these specific books and who use the AR program in their own schools throughout the country but, due to budget constraints, cannot spend the funds on purchasing more ready-made AR quizzes from Renaissance Learning.

This project focused only on creating teacher-made Accelerated Reader quizzes or locating previously created quizzes on the Internet and allowing students to access these quizzes as part of their AR program. This project did not include the sharing of copyrighted Renaissance Learning quizzes that other schools have previously purchased. 
It also does not include simply purchasing AR Practice Reading Quizzes that can be bought from Renaissance Learning

In the future, this type of project could be reconfigured to allow the students themselves to create AR quizzes for books they have read. Probably on this intermediate level, teachers would have to select students with whom they feel could successfully create quality questions leading to a valid quiz. It could be a wonderful activity for students who are higher achieving or who enjoy doing extra "homework."

For further development, multiple teachers within Maplewood could band together in these efforts. Many teachers within the Maplewood Intermediate's $3^{\text {rd }}-4^{\text {th }}$ grade building possess many of the same book titles purchased throughout the years at annual Scholastic Book Fair at the school. The school's AR software does not include quizzes for many of these titles. Teachers could divide the responsibilities of reading the books and creating the quizzes. These could be placed on the AR software for all Maplewood students and teachers to use and enjoy. If used in the future, these two activities would show good use of time, a wonderful use of teamwork, and a wise use of resources leading to greater student benefits.

\section{Significance of the Project}

The company Renaissance Learning, the maker of Accelerated Reader and STAR Assessments, states that it is the world's leader in providing computer-based reading assessment technology for pre-K-12 schools with over 75,000 North American schools using their programs (Renaissance Learning, 2009). Accelerated Reader is a motivating component of Maplewood Intermediate's total reading program. AR is used daily in all 
classrooms and is often used for at home reading assignments as well. Quarterly classroom reading goals are often based on the AR program and meeting these goals results in individual and classroom awards given by the principal. Students also automatically earn points through this computerized program from which they can purchase items on the library's smart cart. This cart is filled with small to large prizes including games, posters, and candy.

Maplewood Intermediate School's library is stocked with primarily AR books. It holds thousands of titles that are marked with the book's Accelerated Reader reading level. Once a week, each class visits the library. Students select books that both interest them and are on their reading level. Giving students these choices makes them feel empowered in their personal learning process. They look forward to browsing the selection and finding just the right books for them.

When a student finishes their book and takes their AR quiz, access to a new AR book from the school library is not often available. It is unavailable to students when other classes are there in their scheduled time, the librarian is covering for the office workers lunch periods, it is being used for a small assembly or breakout session, or when the librarian has her own quiet work time in the mornings. It is often easier to make a general rule that students can only go the library during their scheduled time in order to save the students' time walking back and forth to the library only to find it is unavailable to them.

Students are then directed to select a title from their own classroom library. This is why it is so important to have as many AR titles on all reading levels as possible in the individual classroom library. At the outset of this project, the classroom library consisted 
of 62 Accelerated Reader books on all applicable levels and 48 books for which the school did not have Accelerated Reader quizzes. Of course, many students are more motivated to read the Accelerated Reader books because of the link to technology, points earned, and principal rewards. Because of this, the other 48 titles of appropriate literature often stayed on the shelves virtually untouched. A goal is to provide students the opportunity to gain their AR points and make their classroom reading goals while enjoying these other books of interest in this classroom library. This will show a wiser use of resources that hopefully leads to greater motivation and reading success.

\section{Methods of Procedure}

Initially, all the classroom library books were removed from the bookshelves for which Maplewood Intermediate did not have Accelerated Reader Reading Practice Quizzes. The website arbookfinder.com was searched to ascertain the reading level and point value for each of these books. These levels and point values were marked on the front cover of each book for quick student reference.

Next, the Internet was used to search for teacher-made Accelerated Reader quizzes. Many websites were located that offered these quizzes, but after searching their databases, none of the needed titles were found. Finally, a Yahoo group was joined that consists of teachers that share their teacher-made AR quizzes. Each of the needed book titles was searched. The goal was to find many titles in this way in order to save time; however, only two book titles were found. These two quizzes were utilized for the project. 
Reading and creating quizzes for the remainder of the titles began. The multiplechoice format, length, and questioning style were patterned from samples of the Renaissance Learning AR Reading Practice Quizzes. These quizzes were then manually installed into the AR software at Maplewood Intermediate for instant student use in this classroom and even throughout the building.

After that, students were introduced to the new AR books in the classroom library. They were encouraged to choose some of these new books that were on their level for their daily quiet reading time. As students finished the books, they took the new AR quizzes. Ten titles were chosen from which to study the students' quiz results. The results were compiled once five students completed a particular quiz. To ensure the quizzes were not too easy or too hard, changes to the AR quiz were made if the average quiz score for a specific book title was $100 \%$ or was below $70 \%$.

Finally, these quizzes were shared with others. A list of all the new AR quizzes now available on Maplewood Intermediate's AR software was given to the school's teachers and the librarian. The quizzes were also posted on the Yahoo group message page for all the members to use at their discretion. 


\section{Chapter Two}

Plenary Literature Review

\section{Overview of Accelerated Reader}

Accelerated Reader has been positively recognized by several educational organizations. Two of them are the What Works Clearinghouse and the Florida Center for Reading Research. First, the United States Department of Education's Institute of Education Sciences initiated the What Works Clearinghouse in 2002. Its main purpose is to use research to help educators and policymakers make informed educational product decisions based on reliable evidence. The Clearinghouse gave Accelerated Reader a high rating, meaning the program has "evidence of a positive effect with no overriding contrary evidence" (Student Progress Monitoring, 2006; Renaissance Learning, 2009). Second, the Florida Center for Reading Research found there is "strong support for the efficacy of the AR program in supporting reading growth" (Florida Center for Reading Research, 2006).

To begin the Accelerated Reader program, students take the STAR assessment, also produced by and purchased from Renaissance Learning (Renaissance Learning, 2009). The National Center on Student Progress Monitoring studied the STAR program and concluded that it "demonstrated sufficient evidence to meet the basic standards" in reliability, validity, AYP benchmarks, teacher planning, and rates of improvement (Student Progress Monitoring, 2006). Since the AR program's cornerstone piece is the information received from the STAR Assessments, AR is built on a firm foundation. 
STAR reading assessments are comprised of 25 questions which use adaptive branching, measuring each response and adapting the next question to the correct reading level of difficulty (STAR Program Manual, n.d.). In approximately 10 minutes, students and teachers are given instant feedback as to each student's grade equivalent, based on a norm-reference, as well as their Zone of Proximal Development (ZPD). This zone's name was coined by Vygotsky (1978) well before the AR program existed. In AR the ZPD is the readability range from which students should be selecting books in order to experience optimum growth without experiencing frustration. The grade equivalent score on the STAR assessment determines the ZPD (STAR Program Manual, n.d.). For progress monitoring, students are retested each quarter. Their readability range from their new Zone of Proximal Development will hopefully increase allowing students to select higher-level book titles.

In order to be a part of the Accelerated Reader program, schools must purchase the Accelerated Reader computer software, choose from over 50,000 book titles from which to purchase copyrighted Accelerated Reader Reading Practice Quizzes, as well as purchase the corresponding books for the school library (Pavonetti, Brimmer, \& Cipielewski, 2002). These books have each been given a reading level based on the Flesch-Kincaid reading index as well as a point value based on the length and reading level (Paul et al., 1996). Students then select books marked with a reading level that falls within their Zone of Proximal Development. For example, if a student took the STAR assessment and received a grade equivalency of 3.5, their Zone of Proximal Development may be $3.0-4.2$. Therefore, the student should select a book within this $3.0-4.2$ Accelerated Reader level (STAR Teacher's Manual, n.d.). 
Students then read the book and complete a computerized Reading Practice Quiz over the book just completed. When the quiz is complete, the software allows the student to see the correct answer to the question(s) missed. A TOPS report is immediately printed to the classroom printer. Students are shown the correct number of answers given as compared with the correct number of answers possible. The percentage earned from their quiz and the points earned are also shown on this report. Points are calculated by taking the percentage earned times the total point value for the book. For example, $80 \%$ (earned quiz score) $\times 3.0$ (total point value) $=2.4$ points earned. Students who receive less than $60 \%$ receive no points. Students may not retest over the same title (Pavonetti, Brimmer, \& Cipielewski, 2002). TOPS reports also detail the number of books read along with their corresponding reading levels, quiz scores, and number of points earned for the marking period as well as the entire school year. Teachers can also create customized reports for parent conferences, student conferences, progress monitoring, and to assist in delivering more effective instruction (Vollands, Topping, \& Evans, 1999).

\section{Related Research and the Benefits of Accelerated Reader}

The Accelerated Reader program's benefits include giving students books on their own reading level, providing motivation by allowing students to choose their own books of interest, and focusing on personal reading time with personal accountability measures that also assist in making more effective reading instruction decisions. First, instead of guessing whether a student is truly reading on an appropriate level, using the Zone of 
Proximal Development "maximizes challenge while minimizing failure and avoiding unproductive reading at levels too low or high for successful learning" (Topping \& Paul, 1999).

Through the use of the Zone of Proximal Development, the Accelerated Reader program allows students the ability to self-select books that will lead to success instead of self-selecting books that are too challenging or too easy for the student's current reading level. Individual differences are an integral part of the program. Students become aware of these differences when using the program, and teachers can nurture students by normalizing these individual differences. Teachers can use actions and words to show how to value each person for who they are while encouraging each to celebrate their strengths and be honest about their weaknesses (Oldfather, 2002; Thorkildsen, 2002; Thorkildsen et al., 2002).

Occasionally a book is chosen within the student's ZPD that is sometimes too difficult for a student. The ZPD does not need to be the final word on selecting books; it is a guideline. The teacher can teach students the five finger rule. When reading the first few pages, if they have difficulty with knowing a word or its meaning five times on a page they need to see the teacher and discuss changing to a different book. Sometimes students want to read books above their ZPD. This is possible since interest in a book can sometimes override the challenge of a text since interest is a huge motivator (Greer, 2003). Guthrie et al. (1999) state that one of the major contributions for text comprehension is student motivation.

Motivation is a prominent key for many areas of reading success. Reading motivation is a rich area for research because there are so many reasons to engage in 
reading (Nolen, 2006). Studies show children who are highly motivated to read do so three times more outside of school than other less motivated children (Wigfield \& Guthrie, 1997), and the amount of intrinsic and extrinsic motivation a student possesses predicts the amount of time a child will spend reading (Guthrie et al., 1999). Further studies show, if students are given enough reading material (Neuman \& Celano, 2001), the frequency of students reading is based on two pillars (Cox \& Guthrie, 2001; Paris \& Turner, 1994). One is their motivation to read (Pressley, 2002; Wang \& Guthrie, 2004). The other is their initial success in learning to read (Stanovich, 1984).

Many studies suggest a young child's motivation to read is in alignment with their current reading ability (Chapman \& Tunmer, 1995, 1997; Gottfried, 1990; Lepola et al., 2005; Lepola, Vauras, \& Maki, 2000). The struggling reader who needs to read the most in order to benefit from practice are often the ones least likely to be motivated to read (Chapman, 1988; Lepola, Vaurus, \&Maki, 2000). When asked, low achieving first grade readers thought reading was difficult, they were not good readers, and thought negatively about reading in general. These low achieving students also exhibited more avoidance behavior toward reading activities than the other students in the class (Morgan et al., n.d.). Teachers want to boost reading motivation (Allen, Schockley, \& Baumann, 1995) because these attitudes and behaviors lead to long-term reading difficulties (Baker, 2000; Gambrell \& Morrow, 1996; Quirk \& Schwanenflugel, 2004).

What can teachers do to increase motivation, especially in these struggling reading students? Morgan and Fuchs state scientifically-based interventions should be implemented as well as motivation building techniques (2007). One major motivator suggested by Quirk and Schwanenflugel (2004) is to help children self-set individual 
reading goals. These goals should be reachable yet challenging. As the teacher monitors progress and encourages the students toward the goals, the children's thought patterns about themselves as readers become more positive as they begin to see their progress (Morgan and Fuchs, 2007).

Maplewood Intermediate School uses the Accelerated Reader program as a way for students and classrooms to set attainable yet challenging goals. Maplewood's teachers and students work together to set new goals each quarter. Students, parents, and teachers can track progress toward these goals through the multiple computerized reports available with the AR software. More on the AR reports will be discussed later in the chapter.

Teachers can also assist in motivating their students by being great reading role models (Gambrell, 1996). In a third grade study by Kelly and Clausen-Grace (2006), the teacher showed her students her great excitement toward literature. She read aloud and talked about books she had read throughout the day. She often recommended books for her students according to their interest and both monitored and supported her students during their independent reading time. When students were asked if their teacher was a reader, $100 \%$ responded positively. One student said, "Yes. She talks about all of the books she reads all the time." It is the teacher who can often find the ways for reading not only to be an opportunity for learning but an opportunity for enjoyment as well (Nolen, 2007).

Accelerated Reader books can be read aloud to the class for motivation. The teacher in this project's classroom read aloud an AR book entitled, Charlie and the Chocolate Factory by Roald Dahl (1964). Various types of silly voices were used during 
the read aloud time. Within a few days, every copy of this title was check out of the school library by the students so they could follow along in the text each day. Several had even finished the book a few weeks before the text was finished being read to the class. A discussion about other Roald Dahl books began and soon about a fourth of the class was reading one of Dahl's books. The students took the excitement they saw from the teacher and multiplied it.

Choice is also a major motivator. Motivation is defined by Guthrie and Wigfield (2007) as "beliefs, values, needs and goals that individuals have." In order for students to have a sustained interest in topics and show an expansion of their efforts, their reading tasks need to be as close to these personal beliefs, values, needs and goals as possible (Pitcher et al., 2007). They want to see how these tasks will personally benefit them in some way.

There is a positive relationship between literature and motivation when students are allowed self-direction and social collaboration as well as access to interesting texts (Guthrie \& Knowles, 2001). When asked, students listed choice as an important piece of their literary tasks (Ivey \& Broaddus, 2001; Oldfather, 1993). Hidi and his colleagues suggest there is more than a sense of autonomy when choices based on interests are involved. Students also feel empowered because of their prior knowledge of the subject matter and use it to better understand the new literature (Hidi \& Anderson, 1992; Hidi et al., 2002). Reading literature of interest also nurtures the feeling of positive emotions and makes success more likely for students (Pajares, 2003; Pekrun, Goetz, Titz, \& Perry, 2002; Walker, 2003). 
In Nolen's 3-year longitudinal study (2007), reading motivation was studied in several schools over the course of the primary grades 1-3. The biggest change in the motivating factors of students that was constant between the studied schools was a substantial increase in reading for their own interests as children grew older. In Grade 1, $47 \%$ of students said they were motivated to read when they read books that interested them. In Grade 3, 91\% of the students selected reading for their own interests as a motivator. The motivator of reading for the mastery of the skill fell to about $33 \%$ by Grade 3. By this time most students knew how to read fairly well and wanted to use reading to satisfy their desire for specific books or topics instead of simply learning to read for its own sake.

As students read more and their perspectives change, their reading interests will broaden with time (LaBrant, 1958). Giving children access not just to more books, but to a broader variety of books topic will be needed as time passes. Adding more quality books to a library is always a plus because access to more books leads to more reading and more reading leads to better reading (Krashen, 2004). Strommen and Mates (2004) summarize by saying if reading for pleasure can bring about more reading achievement, then teachers encouraging their students' love of their chosen literature of interest is a viable goal.

Accelerated Reader is based on student choice of literature. The ZPD gives students a reading range from which they can self-select their own reading materials. They can go to the teacher for recommendations, but the power is given to them to make decisions on their own within their ZPD. It allows them to feel empowered, capable, and able to read for their own personal enjoyment. The previous research given promotes 
these factors as motivators. This project was created to give students even more access to a variety of $A R$ books and thus to the benefits and motivators of this program.

Studies show that students who read more not only read better but have superior spelling, writing, vocabulary, and grammatical skills (Krashen, 2004). Reading frequently also brings gains of sight word recognition, fluency, reading comprehension, and general knowledge (Cunningham \& Stanovich, 1991; Echols, West, Stanovich, \& Zehr, 1996; Griffiths \& Snowling, 2002). According to Allington (2006) and Davidson and Koppenhaver (1993), there are two predictors of successful reading. First, it is essential to have a dedicated time for students to independently practice their reading, and second, there needs to be created culture of literacy.

In the 1990's Sustained Silent Reading (SSR) was a common practice in many schools. It was a time for students to self-select their book and read for a specific amount of time. (Kelley \& Clausen-Grace, 2006). Oftentimes, teachers were told they should also be reading a book of their choice quietly during this time in order to model behavior for students (Stahl, 2004). Students involved in the traditional SSR time did not have any accountability measures or follow-up activity for their personal reading time (Pilgreen, 2000; Reutzel, Fawson, \& Smith, 2008). Time was not always being used wisely. Today SSR time is often a hard sell (Krashen, 2009).

Sometimes a strategy needs to be implemented more effectively instead of simply removing it because of its flaws (Kelley \& Clausen-Grace, 2006). Kelly \& ClausenGrace took the traditional SSR plan and reworked it to include appropriately leveled books for all students, accountability, and times of discussion. They stated that every 
child became more motivated from the most reluctant to the previously engaged readers in the class.

Some may argue that taking time in the school day for students to independently read takes away valuable minutes from reading instruction. However, Krashen (2004) found students who had independent reading time during the school day scored the same or higher on standardized reading achievement tests than those students who did not have the individual reading time during school hours.

Krashen (2009) discusses how using chess, Latin, roller skating, physical education, and intensive phonics instruction have all been applauded as major reading breakthroughs. After he completed many research studies himself and with his colleagues, he strongly believes the best method to improve reading abilities is to consume large amounts of "interesting, (better yet, compelling), comprehensible reading." He states it may be the least expensive, most pleasant, and most obvious of all the choices, but unfortunately, it is often overlooked.

Accelerated Reader does not overlook personal reading time. The program promotes large amounts of personal reading. At Maplewood, students have a 25 minute block of time per day for this personal reading time. If a child finishes the book, they may immediately go to a classroom computer and complete the AR quiz. Instantly a report is printed for the student and teacher. This provides a convenient opportunity for dialogue between the student and teacher. Honest conversation based on the student's thoughts about the book and the student's performance on the quiz can happen easily at this point with the report information available. 
A study by Bryan, Fawson, and Feutzel (2003) found that SSR students who had brief accountability interactions and conferences with their teachers stayed on task during SSR for up to three weeks without any other accountability checks after the first interaction. Student discussions and teacher conferences were also used during SSR time, and they worked much more effectively than having the teacher simply modeling reading as found in Manning and Manning's work (1984). Student reading scores increased slightly when these measures were taken.

One of the best things about Accelerated Reader is the accountability students now have for this learning time. Teachers, parents, and students can view their efforts. As the Practice Reading Quizzes are taken, there is instant and accurate feedback given through the myriad of reports available. For the teacher, it is easy and time effective. A teacher can track how many AR books a student has read and the quiz scores that relate to effort and comprehension (Renaissance Learning, 2009). The teacher can use this to make more effective decisions in encouraging and directing students in their individual reading conferences.

For example, there was a student in the third grade classroom at Maplewood Intermediate who appeared to be diligently reading during the 25 minutes of SSR time during reading class. However, reports that were printed out for her showed an alarming pattern. She was taking at least two, if not three quizzes per week, but not passing any them. Upon further inspection of the titles of the books she was reading, they were all medium-sized chapter books that would take her more than a day or two to read correctly. After conferencing with her, she admitted she was not reading the books at all but simply taking the quizzes. The accountability and information given from these reports allowed 
the teacher and student to share concerns, frustrations, and interests as to lead her to greater reading achievement in the future.

Reports can also be used to alert parents to their child's personal reading time. A student's performance for any given time period can be tracked using the summary reports. A summary report is often sent home in the middle of the grading period that details their child's performance thus far in the grading period. Parents can specifically discuss the progress with their child and encourage them on to make their new quarterly goal.

The National Reading Panel also stresses the importance of giving students feedback about their reading (NICHHD, 2000). Students like this instant feedback too. They can read a book and determine how they performed and what they could do better the next time. This enables students to have greater control over their own reading activity. Students critically think through and manage the appropriate challenge of their past and future book choices (Shapiro \& Cole, 1994). They also feel better about themselves as a reader (Schunk, 1994; Schunk \& Rice, 1993). From these studies, it seems since AR students have personal control in this program, it can be highly motivating.

\section{Overcoming Limitations and Barriers of Accelerated Reader}

There are limitations and barriers to the Accelerated Reader program, but there are steps to offset them. Perhaps the most important limitation to understand is that although Accelerated Reader can be used to differentiate for students, it is not a standalone instructional program (Biggers, 2001). Schools should use this system as a 
supplemental tool and not as the basis for their reading curriculum (Greer, 2003).

Especially with struggling readers, Morgan and Fuchs stated that scientifically-based interventions are necessary to help these students even though they also heartily believe in using motivational techniques to improve success (2007).

Not only is direct instruction missing, but also the quizzing piece in Accelerated Reader is completely fact oriented in multiple-choice format. There are no extended responses or short answers. All of the higher levels of questioning in Bloom's Taxonomy including inferential, creative, and critical thinking skills are obsolete with these AR Reading Practice Quizzes (Florida Center for Reading Research, 2006). Therefore, it is simply a piece of the reading puzzle - a means of assessing whether a student read and comprehended the text. Maplewood Intermediate uses AR as a supplemental piece that has been added to our basic basal program where instruction that includes higher level thinking skills in large and small groups is given.

Secondly, the cost of the Accelerated Reader program requires an investment. Schools can purchase Accelerated Reader kits to get started. Depending on your budget, the kits can are comprised of the Accelerated Reader software and 50-1,000 AR Reading Practice Quizzes. However, schools must also separately purchase their own trade books that match the titles of the Reading Practice Quizzes purchased. Schools may also choose to purchase the STAR Assessment software that is also projected by Renaissance Learning (Pavonetti, Brimmer, \& Cipielewski, 2002). It is possible to use the AR program alone, but the student and book reading levels are based on the Zone of Proximal Development from STAR. 
As the schools continue to want to add to their Reading Practice Quiz selection and books in their library, they may purchase additional quizzes from Renaissance Learning without purchasing another kit. At Maplewood Intermediate, the library did not have the budget to purchase new AR quizzes for this group of classroom library selections, nor a new companion book for the school library. This limited classroom AR choices for this group of students. To help combat this, teachers can take their own classroom library books that are not a part of their school's AR collection, create their own quizzes, and install them on their school's software so their own classroom library books are available to their classroom students for AR purposes. They can also do as was done in this project and search the Internet for previously created quizzes for their classroom titles.

Thirdly, great attention needs to go towards the appropriateness of the AR books offered to students. As the reading levels get higher, the appropriateness of the text sometimes comes into question. Just because something is a 4.7 level, does not mean that a 3rd grader with a higher reading level would be equipped to take in the content. Several of the third grade students in the project classroom earned a grade equivalent of 7.1 near the end of the year. Their parents were alerted that most of the titles available on this higher level of reading material were unfamiliar to the teacher, but there would be a brief screening of any books in the library that their child would consider reading. A strong request for monitoring the appropriateness of the literature from home was given as well.

Pavonetti, Brimmer, \& Cipielewski (2002) have documented a similar issue. A mother was reading an AR book with her son at home. The book was a 5.0 level and was 
entitled Mr. Was by Pete Hautman (1996). The story details physical and verbal abuse, alcoholism, AA meetings, and graphic murder. Most would find this completely inappropriate for a child in elementary school. From this, the benefit of reading each book and creating teacher-made quizzes when dealing with a teacher's own classroom library is made clearer. Throughout reading this classroom library collection, two books from a popular pop-culture book series were found that were well within the reading level of several of my students. Students would have been drawn to the titles. However, they have not been placed back on the classroom shelf. Several of the events and topics dealing with dating, bullying, and popularity included in the text were found to be slightly too mature for a $3^{\text {rd }}$ grade student.

Some believe the Zone of Proximal Development that is used to give students a guideline for selecting the difficulty of their books boxes them in to a narrow section of literature they might not be interested in reading. A student may be excited about a certain series or topic of books, but their reading level does not allow them to enjoy these books within the parameters of the AR program. This can be handled several ways. If the book the student desires is far above their level, and they will not be able to reach that level for quite some time, they can be allowed to check out the book. A quick note could be written to their parents stating that this book is probably too difficult for them to read alone, but would be a great book to read together. Even highly competent readers benefit from reading with someone when they want to read a text above their comprehension level (Topping \& Lindsay, 1992; Vanwagenen, Williams, \& McLaughlin, 1994).

Another way to handle this is to use it as a motivating challenge for them to continue to improve their reading in order to score higher on the next STAR assessment. 
At that time, they will be allowed to check out this book. However, if the book is just a few tenths of a point above their level, they could be allowed to try it out for their AR book.

Sometimes, the rules can change depending on the student and situation. For example, there was a great reader in the third grade class whose goal was to read the entire Harry Potter series by J.K. Rowling. This follows other research that as student develop more stable interests, they will move from wanting to read specific books to wanting to read books in a series (Nolen, 2007). Some of the Harry Potter books were within his ZPD; however some were one or two grade levels above his level, a huge difference. After seeing his passion for the series, he was allowed to continue on, and he managed just fine. This excited several other high achieving readers in the class to do the same. Interest in a book can sometimes override the challenge of it due to the motivating power of student interest (Greer, 2003).

The same can be applied to a child who has a desire to choose an AR title a few tenths of a point under their ZPD level. Guthrie et al. (1999) states that one of the major contributions for text comprehension is student motivation and this motivation will result in an increase in reading which then leads to an increase in the student's reading comprehension.

Lastly, the AR program can be followed as a very basic program - select, read, quiz, and print report. Teachers would be wise to remember the effects from Kelley \& Clausen-Grace (2006) study where the teacher encouraged students by sharing her passion for literature in order to further motivate students. Also, this program can be done without teacher conferences and discussions, but remembering the work done by 
Bryan, Fawson, and Feutzel (2003) and Manning and Manning (1984), students stay much more on task when teachers are involved with students during sustained reading time. Teachers can mold this program to be even more effective with the given research information. 


\section{Chapter Three}

\section{Methodology}

\section{Collection and Creation of Quizzes}

The process began by removing the section of the third grade classroom library books for which Maplewood did not have Accelerated Reader Reading Practice Quizzes

in their Accelerated Reader software. Several co-workers heard of this project and shared a time saving tip. They had seen several sites on the Internet where teacher-made AR quizzes could be downloaded which could save large amounts of time reading and creating quizzes if the proper titles could be found. For this benefit, an Internet search was started to discern if there were already teachers who had previously made quizzes for the desired titles from the classroom library. Several sites that had many of these quizzes were found; however, none of the needed classroom library titles were available. I bookmarked these sites on the classroom computer for future continuations of this project when other books need a teacher-made AR quiz.

Finally, a members-only Yahoo group was discovered. It is designed for teachers to share their teacher-made AR quizzes. To become a member, the facilitator of the site must approve you after asking you a series of questions. One of the main points the facilitator clarifies is that this is for the sharing of teacher-made AR quizzes. The sharing of copyrighted AR Reading Quizzes purchased from Renaissance Learning is strictly prohibited. Also, members of the site must contribute to the number of AR quizzes for the benefit of all the members instead of just using the resources available. When the facilitator learned the nature of this project, membership was easily approved. Initially, 
their lists of quizzes were searched, and two of the needed titles were found. This site quickly provided the Accelerated Reader book level, Accelerated Reader point value, as well as quality questions and answer choices for each of these two titles.

Next, arbookfinder.com, a website designed by Renaissance Learning, was used to ascertain the AR book level, AR point value, and word count for each of the remaining titles, all of which are needed in order to manually input a teacher-made Accelerated Reader quiz into the school's AR software. The book level was marked on the front cover of each book in order for students to easily find their desired level.

Generally, most copyrighted AR Reading Practice Quizzes from Renaissance Learning are a total of 10 questions. The number of questions on a quiz is based on the book's length, complexity, and reading level (Institute of Academic Excellence, 1998). From being exposed daily to these purchased quizzes, it seems books with only a few short chapters or no chapters at all are assigned five questions. All of these quizzes are in multiple-choice format with four answer choices. With this pattern in mind, the reading and creation of multiple-choice comprehension questions and answer choices for each title began.

Since Maplewood utilizes the AR program daily, modeling of the types of questions and patterns of the copyrighted quizzes was easily accessible. These new teacher-made quizzes were patterned this same way as the copyrighted quizzes using the first two levels of questioning from Bloom's taxonomy (Overbaugh \& Schultz, n.d.) - the knowledge level which deals with remembering facts and the comprehension level which deals with understanding a selection. On occasion, a few questions from the next two levels of the taxonomy were included. On the level of application, a sample question 
would be, "Based on what you know about Sarah, what would she like to receive for a Christmas present?" On the fourth level of analysis, a sample question for a non-fiction book would be, "If a description of toucans were added to the selection, in what chapter should it be placed?"

\section{Implementation Procedure}

After the quizzes were created, they needed to be installed in the Accelerated Reader software at Maplewood. Since this was a task the school librarian in charge of AR did not even know how to do, the Accelerated Reader User's Manual was used to learn the appropriate procedure. After trial and error on several levels, the installation became easier. The task required an assignment of a new quiz number for each book. Each installation needed the book title, point value, word count, book level, questions, and answer choices. The correct answer choice was to always be inputted first in the list of possible answers. When the quiz was fully installed, the correct answer was randomly assigned a position within the incorrect answers. Each installed quiz could be viewed for perusal, edited for corrections at any time even after student use, and printed for a resource. Once installed, any Maplewood student or staff member, not just those in this designated classroom, gained access to these new quizzes.

These books were then placed in a special new area on the classroom library bookshelf that was divided into categories for the various reading levels of each title. This provided quick access to a book of a specific reading level and ease of use for students. Since the students were aware this AR project was taking place, they were 
exciting to see the removed books returning to the shelf and began asking if the new quizzes were ready.

During a reading period, the students were told about the new teacher-made AR quizzes available and encouraged to select their next silent reading book from this group of new AR titles. Over the course of the next few days, each book was introduced by showing the cover art, giving the Accelerated Reader level, and sharing exciting points from the characters, setting, and/or the plot that may draw certain students in. Students were so excited about this group of classroom library books that previously used to just sit on the shelves because there were no AR quizzes for them. Several students had to be strongly encouraged not to rush through the book they were already reading in order to choose one of these "new" books.

\section{Data Collection}

Over the next few months, TOPS reports, which give various information about a student's performance on a specific AR quiz as well as the total percentages of all AR quizzes taken within the grading period and the entire school year, were used to track the students who took these new quizzes and the scores they received. For measures of reliability, after approximately five students took a specific title's quiz on their own reading level, the average of the earned scores for that quiz was calculated. If the average was $100 \%$, the quiz was deemed too easy. If the average was below $70 \%$, the quiz was deemed as perhaps being too difficult. In the end, of the 48 quizzes, no quiz averages were $100 \%$, but there were four quizzes that earned averages below $70 \%$. These quizzes were reviewed to see if any question was not clear, too difficult, or too detail-oriented. 
One or more changes were made to each of these four quizzes. Next, for each of these four quizzes, five other students who were on the book's reading level were asked to read the book and take the quiz. These scores were used to find the new earned averages for each title. This time the averages were between $80 \%$ and $90 \%$, and the difficulty of the quizzes was deemed satisfactory. Table 3.1 illustrates these results below.

Table 3.1 - Reliability Testing

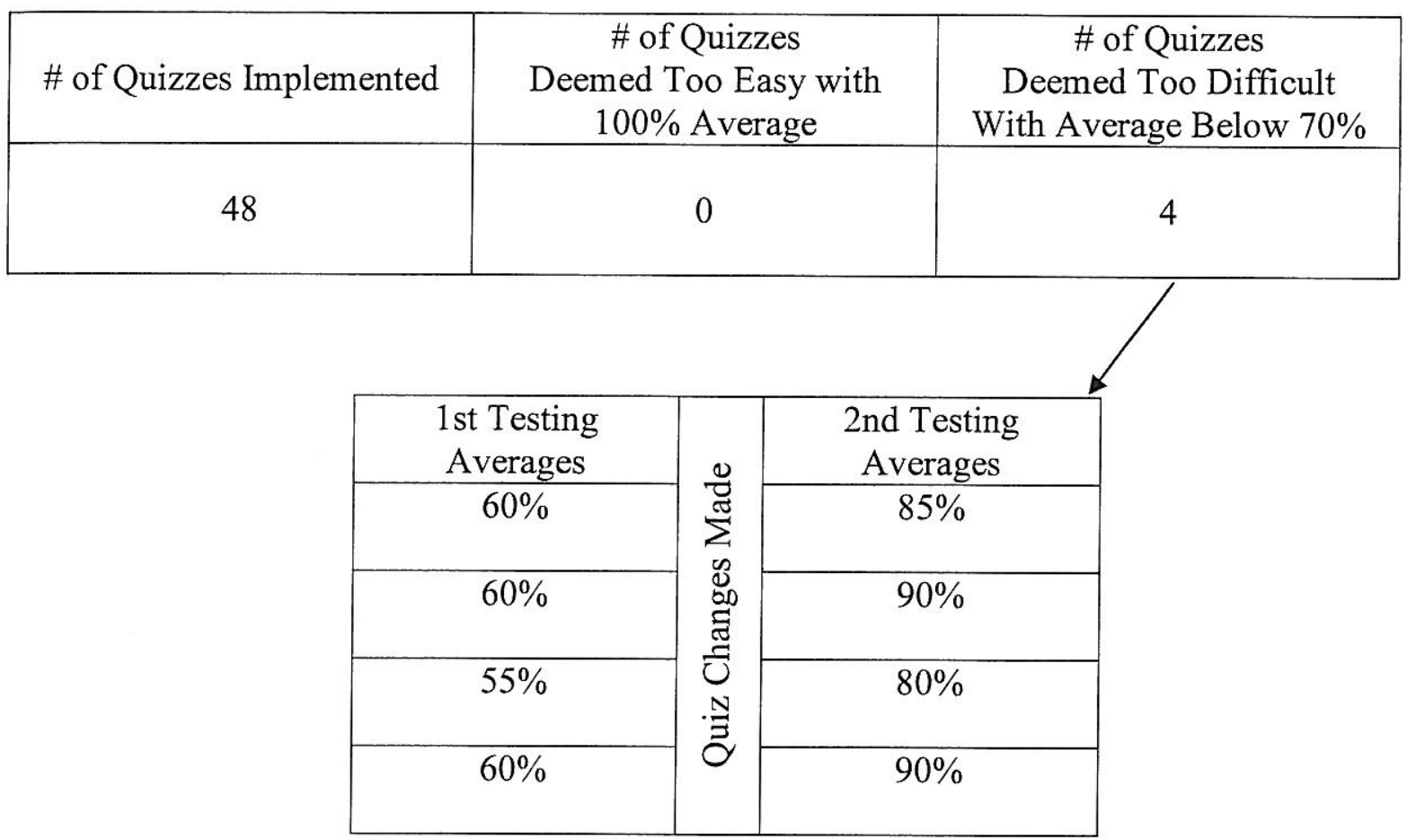

\section{Distribution of Information}

After spending this time incorporating the books and their quizzes in the classroom, Maplewood's librarian was given a list of the new AR quizzes available on the software to use at her own discretion. She was quite pleased that a teacher was using the program in this way. She stated that when monies become available, she will 
consider purchasing several of the more popular titles for the school library and labeling them as AR quiz books just as the thousands of other AR books in the library are labeled.

A memo was also placed in each of the staff mailboxes at Maplewood that alerted them to the new quizzes available on the AR program. Many of these classroom library book titles used for this project had been purchased at several of Maplewood's annual Scholastic Book Fairs. Many of the teachers may also have purchased these books for their own classroom libraries and could alert their students that a book now has an AR quiz for students to use. A list of these 48 new AR quiz titles was placed in the staff lounge for staff perusal at their convenience. Several teachers did have some of these titles in their room and shared this information with their students. Several former students shared their pleasure about the new AR quizzes when passing in the hallway. These new quizzes were also posted on the Yahoo AR group website for all its members to use at their discretion. When the large list of new quizzes was posted on the site, there was a grateful response from the group's facilitator as well as several of the other members. On this site, a teacher usually only posts several quizzes a year as the need to create a new quiz arises in the classroom. Seeing so many new quiz titles at once, especially titles available throughout the country from annual school Scholastic Book Fairs, the members were pleased and let me know that many of these titles were books on their own classroom library bookshelves. 


\section{Chapter Four}

Project Findings

\section{Integration}

At the beginning of each quarter, the students complete the STAR Assessment. They place their results in the form of the Parent Report in their data binder. This report includes their grade equivalent and Zone of Proximal Development which is also their new Accelerated Reader level. Students take this binder home one or twice a month so parents can monitor their child's progress in multiple academic areas. This new Accelerated Reader level is placed on their personal library card for easy reference. If students desire a slightly higher or slightly lower level book than their level allows, they must explain why they desire this book. The teacher makes the final decision if they are allowed to use this for their new silent reading book. Many times it is a yes, while other times it is a no. Students usually are able to select this book if it is close to their current level. If it is a no, it is explained to them that they need to prove they can get a higher level on their STAR test in order to earn the privilege of getting this book next quarter. More detail on checking out AR books outside of a student's ZPD was given in the Benefits section of chapter 2 .

As a class, the students visit the school library once a week. Students may check out two books at a time. One must be an AR book on their level; however, the other can be any other book. Students often need a new AR book before it is time to go back to the school library. This is when students are free to go to the classroom AR bookshelf to 
select a new AR silent reading book. This is why it is so important to keep as many books on all levels in the AR classroom library.

Students have even brought in used books from home to add to our AR collection. Students use the AR software to check and see if there is an AR quiz for a specific title already in our school's software. If so, they mark the reading level on the front of the book and place it on the appropriate shelf. If not, they place the book in the "I need an AR quiz" stack. As time permits, the books are read and a quiz is created for each title. When the quiz is put into the AR software, the donating student introduces the book to the class by showing the cover art, describing the main character, and explaining the general plot of the selection without giving away too much of the story, especially the ending. Unfortunately, this happened on several occasions. Students also explain why they recommend this AR book to their classmates.

At the beginning of each quarter, the school requires each classroom to create classroom and/or personal reading goals. Though they can be based on anything the teacher chooses, in this classroom, the Accelerated Reader program is used for most of the reading goals. If individual goals are being used, each child is given assistance in order to make a challenging yet reachable goal. For classroom goals, the students and the teacher discuss and choose the goal. One quarter the class goal was to read and pass the quiz for 120 AR books. Each student was to contribute at least 5 books to the classroom's total. Another quarter, the class may follow similar guidelines, but the total number of AR points earned will be calculated instead of the number of AR quizzes passed. This makes the goal even more challenging as students cannot get by with 
reading several small books worth half of a point while others are reading large chapter books.

Each quarter, the students are challenged, and seem quite motivated, to increase the class goal. The first quarter of the year, the class only earned a total of 50 AR points. The third quarter, the students wanted to make 120 points, yet they earned 423 points. The last quarter, the students choose to highly challenge themselves and raised their goal to 500 points. Though it was challenging, they made it with 3 points to spare a few minutes before the end of the deadline day!

These goals are recorded and tracked in their personal data binders. Periodically, summary reports for the progress thus far in a given quarter are printed, placed in the binder, and taken home for parent perusal. From this, parents feel informed about their child's progress and students are often encouraged by their parents to keep working toward their goals or even to challenge themselves even more.

At the end of the quarter, students place the quarter's Summary Report in their data binders and write a reflection. The reflection states whether the goals were met as well as the reason the student perceives these results were achieved. For example, "The class reached this goal because everyone used their time wisely during silent reading time," or "The class did not reach this goal because we need more interesting books to choose from." The students seemed to love the personal control they had over their quarterly reading goals. One student commented to the teacher, "I feel like a grown-up. I have to keep track of all my work in my binder just like if I had a real job." 


\section{Key Themes}

AR has been very motivating to this classroom of students who are on a wide variety of reading levels. The principal announces each class goal and the results made during each quarter's school-wide awards assembly. He also awards each class that makes their goal with a Read-A-Thon. Students look forward to this morning of reading their choice of books, comic books, or magazines while lying on the floor on blankets and pillows. The lights are turned off, and the students read by flashlight. It is one of the highlights of each quarter, and most students showed great effort in order to reach their personal goals and do their part in reaching classroom goals.

At the end of each quarter, the school library also rewards students with prizes based on their AR points. Students are called to the Smart Cart where each prize is given a point value based on the points earned from the AR program throughout a quarter. Students may spend all or part of their earned points. They may also choose to save all their points until the year's end. Many children do this in order to buy a Webkinz or other large prize.

Another positive to the AR program in my classroom was simply the fact that $A R$ quizzes are computerized. The students love the computer! A normally mundane task becomes more exciting just because it is performed with technology. The question arises if most of the students like the AR program because of the prizes they can earn or if they read just so they can meet their reading goal and have the Read-A-Thon. It was found out these two options are not the only reasons this classroom of students has been drawn to the AR program. At the end of the school year, all AR quizzes had to be completed by a specific day about a week and a half before the school year was over. This allowed 
final paperwork to be completed. The students were told they were still expected to silent read using AR books, but the quizzes would not count anymore. They could take the quizzes, but they would not receive any points or rewards. It was very surprising to see the number of students who continued taking the quizzes. When one student was asked about this she said, "I love to be on the computer." Another student said, "I just like to see my score on the quiz to see if I did a good job reading."

AR also allows the students to enjoy literature not only on their reading level, but after adding these new titles that included sports figures, animal non-fiction, and books based on current pop culture icons, they had literature of high interest to them. McQuillan (1998) found that in order for students to gain high levels in literacy, they needed the ability to access high interest books..." Once again, the school library held many books on similar topics, but students responded so strongly to having them in their own classroom.

At the beginning of the year, a high-achieving male student in the classroom could not be coaxed to read more than one or two short chapter books during the entire quarter. His reading skills were not improving. During a weekly trip to the school library, he was watched very carefully. It seemed he was not wasting time or playing around, but he was truly interested in finding a good book but seemed frustrated. He did not check out a book at all. After the teacher conferenced with him later in the day, he stated that he couldn't find any more books he really wanted to read. After discussing his interests, he wanted to read high adventure books that were suspenseful and a bit scary. Several AR titles that fit into this description were shown to him from the older and newer sections of our AR classroom library as well as an AR series of books from the 
school library. From then on, he had a book on his desk every day. He pulled it out every second he could find, even during science class. Normally, a teacher would be quite upset with a student who tried this type of behavior, but under the circumstances, it was thrilling to see his zest for silent reading. He reluctantly put the book away but pulled it out the second class was over. He earned the high AR point earner award for the following quarter and became great at recommending these types of books to others in the class.

The most important and unexpected theme seen in this project was the motivating power that came from the sharing of literature. It was quite amazing. When the "new" AR books and quizzes were shown to the class, it was very surprising to see the students' reaction to these new AR books. After all, the school library holds thousands of AR books on many subjects and all reading levels. Somehow, having 48 new choices in their own classroom was exciting and more motivating to them.

As a portion of several days was taken for the teacher to introduce and recommend each new AR book to the class and specifically to individual students who the teacher knew would enjoy the text. The students became more motivated for their personal reading time than had ever been seen. They started saying they needed a certain book before anyone else. As students began reading these selections and knew the teacher as well as others had read them, students wanted to interact with the teacher and other students about books more than ever before. They also wanted to quickly start another book they were interested in as soon as they finished one. It was during this time that students far exceeded their $3^{\text {rd }}$ quarter classroom reading goal of 120 points. They earned an impressive 423 points instead. This is more evidence that previous research 
cited is correct. There is a positive relationship between literature and motivation when students are allowed self-direction and social collaboration as well as interesting texts (Guthrie \& Knowles, 2001).

During indoor recess, several students were sharing about the AR books they had just finished reading. The students went to the bookshelves and showed the others where to find these titles. This sharing of literature was also seen in a research study involving personal reading time and literature (Pitcher et al., 2007). Of the students interviewed after the study, most said they went to get books from the teacher or from the school library that classmates had told them about. The teachers also became a strong source of literature recommendations. Some students even said they discovered the "most interesting story or book read recently" from their teacher. The teacher's enthusiasm about literature in this classroom had great impact on many of the students' reading habits and attitudes.

This behavior was incredible and needed to be nurtured, so a bulletin board with AR book recommendations was created for student use. Each student would have an area on the board to post a brief review of a book just read. At first, a template was given for students to fill out, but after a few weeks, students began to design their own reviews using pictures, designs, and styles that showcased their own ideas and imagination. This board created much excitement as students wanted to know what book their friends were recommending. It seemed to make them see the class as a team working together to help each other.

This board led to a student demand of certain titles that the classroom library could not supply. A waiting list for several books in the AR classroom library had to be 
created. Many trips to the city library were made by the teacher in order to find multiple copies of specific titles in order to meet the students' demand. The teacher taking the time to introduce books to the class in an exciting way as well as students knowing the teacher has read the book they are reading brought the sharing of literature to a new level in the classroom. These strategies will be used even more in the future. 


\section{Chapter Five}

Discussion and Implications

\section{Biblical Integration}

The goal of a Christian educator should be to provide a Biblically based education for all students in the classroom. Biblically based education does not need to transpire in a Christian school setting, just as living a Biblically based life does not have to be limited to working and living within a separated Christian community. As Christians, our worldview needs to engulf every area of our life. A worldview guides and directs a person's life. It tells how to behave in society in order to reach the desired goal of how the world or a person's life should be in the future. A Christian worldview should cause teachers to view and use all aspects of education differently than the majority worldview. Christian teachers should perceive students as being God's own creation. Each is fearfully and wonderfully made as stated in Psalms 139:14. God wants to use each one for His glory.

The majority worldview of education is to learn and become successful in a career in order to earn as much money as possible. It is self-centered. A Christian teacher should strive to make education an opportunity to use knowledge to serve others and ultimately glorify God. Teachers need to make their Christian worldview culturally relevant. This can be done by applying Biblical principles to normal life within the culture norms by means that are appropriate in specific settings, even within the walls of public schools. 
Stewardship is one of the foundational principles necessary for Biblically based education. Stewardship is shown when we use our talents, abilities, knowledge, and resources to care for the spiritual, mental, emotional, or physical needs of others (Baumann, 2009). The focus is on glorifying God by ministering to others and inspiring others to act in the same way. This should be an educational objective each day. If we live in light of these facts, the way we educate our children should be a mirror image of our priorities in life.

It is somewhat easy to model stewardship within the church walls, but we cannot compartmentalize our lives by only being good stewards in the "spiritual realms." We need to adhere to these principles in all areas of life. In Christian or public education, we must train students to be wise stewards of all their knowledge, abilities, and resources. Having materials in the classroom that are not being used to bring maximum increases in student learning is a misuse of resources and a poor example to students who are watching so closely.

The books used in this project have been on the classroom library bookshelf for several years, but most students have not utilized them. The students are more motivated to read titles with Accelerated Reader quizzes due to the goals, rewards, and technology involved with the AR program. In order to be a good steward of the classroom resources, these quizzes needed to be created for these titles so they would be used for greater academic improvement. Using these resources more wisely brings glory to God and is an example of good stewardship for students. In fact, after the implementation process of this project was completed, the class had a discussion about the project. 
The class brainstormed all the good and any bad aspects this project created. One

of the items brought up for discussion was started by a student who stated, "Those books were wasted before. Now we use them more than the other books." This led to a discussion about what other items in the classroom were being wasted and what we could do to use them more wisely. The next day's student journal entry was about any item in their bedroom that was not being used wisely and how to change that. These entries lead to further discussion about donations to less fortunate people as well as asking for more when we already have enough. Stewardship of using our resources wisely was being taught, discussed, and learned.

\section{Strengths of the Project}

The most important strength of this project was that it provided the students with a renewed hunger for reading. As discussed earlier, the class improved from earning 50 AR points the entire first quarter to over $500 \mathrm{AR}$ points in the last quarter. The process began by the teacher sharing highlights of 48 new Accelerated Reader books. As students began reading, they were sharing their ideas about their books orally in formal and informal social collaboration settings as well as through the use of the bulletin board for literature recommendations. This bulletin board became the hot spot during indoor recess for a number of students. A waiting list had to be formed to accommodate the desire to read certain titles with newly created quizzes, and the city library was frequented in order to borrow more copies of these texts. A set time was created for students to give 30 second presentations of their recommendations. If time did not allow this sharing time each day, the students were disappointed and wanted it later in the day. 
For next school year, this encourages time spent each week to introduce and share information about the plot and characters of a variety of AR books in the classroom library. Hopefully, next year's students react the same way to these strategies.

This project showed the huge importance of knowing the literature your students are choosing to read. In this project, since the teacher read each book for which a quiz was created, the ability to knowledgably recommend books was like never before. This knowledge gave the ability to point out specific features of a text a specific student might enjoy. As the students were in the midst of reading their selections, the teacher could intelligently carry on discussions with them about the events and specifically ask them critical and creative questions relating to aspects of the text. When the students were finished reading the selection, the teacher could carry on a much more informed conversation with them about the plot, themes, and lessons to be learned from the selection. Because of this, students were receiving much more feedback and discussion from their silent reading materials. Students seemed to be more excited to read the books and talk about them when they knew the teacher had already read it. One student stated, "My mom said I can only stay up until 9:00 tonight to read my book. After you told me about the scary part yesterday, I tried to get to it last night but my mom made me turn out the light at 9:30."

The amount of successful independent reading completed this year did not come about simply by using the Accelerated Reader program and giving SSR time. Both have been constants in the classroom for several years where it was utilized in a very basic sense - select a book, read a book, take a quiz, and earn a prize. The increase in the amount of successful independent reading seems to have come from how the program 
was implemented with more components. Table 5.1 illustrates how the teacher and student collaboration and sharing of knowledge made all the difference!

Table 5.1 - Achievement and Variables

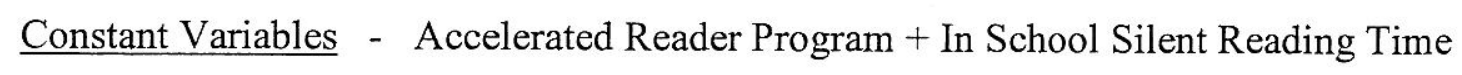

\begin{tabular}{|c|c|c|}
\hline & $\begin{array}{c}\text { Other Variables } \\
\text { Implemented }\end{array}$ & \\
\hline 50 AR Points Earned & $\begin{array}{c}\text { Teacher and Student } \\
\text { st }\end{array}$ & $4^{\text {th }}$ Quarter \\
Social Collaboration with & 500 AR Points Earned \\
& Literature & \\
& $\begin{array}{c}\text { Teacher's Knowledge of } \\
\text { Student Literature }\end{array}$ & \\
& & \\
\hline
\end{tabular}

This project was a success because it improved interest and enjoyment of reading that came about from the stewardship of resources and a sharing of our knowledge and emotions. Those involved gained valuable experiences. Lessons were learned to continue reading improvement for years to come.

\section{Limitations of the Project}

Accelerated Reader is a program this teacher loves to use in the classroom. It can be fun, motivating, and challenging to many students. However, it is only a piece of the reading curriculum not the reading curriculum. It is not a panacea for struggling readers. It does not teach a student to read. It is also not a program that will give higher achievers all they need to advance. Students need direct instruction, especially in the small group 
setting, so they can interact with literature in more critical and creative ways. AR is a tool for reading practice (Renaissance Learning, 2007). This program cannot offer and was not created to offer all aspects of a quality reading program.

Secondly, although this program motivated most students in the classroom, the variety of books, self-choice, points, rewards, technology, or the sharing of literature with classmates did not motivate a few of the students at various times throughout the year. These students did not want to read for no other reason that could be found except they did not want to do it. They refused to do so even with the rewards and benefits offered from this program and from the school. Even after meeting daily with several students in order to find books that would truly interest them and encouraging them daily to read to meet their goals, their silent reading efforts fell very short. They missed out on the personal success, prizes and Read-A-Thon associated with meeting personal and classroom goals. This was not the answer for them, and AR should never be considered the motivating factor for all.

\section{Suggestions for the Future}

The continuation of adding new teacher-created AR quizzes to the classroom library is planned for the future. As students bring in old books from home or new books are purchased at book fairs, new quizzes will be created in order to increase student choices. But as students request specific new titles for purchase, the school librarian will be asked to purchase several copies of the text for the school library as well as a premade Accelerated Reader Reading Practice Quiz if one is available. The school library sometimes possesses the monies to purchase new items throughout the year. If the funds 
are not available, perhaps a wish-list of books could be added to the classroom's weekly newsletter so parents could have the opportunity to donate desired items for their child's classroom library. The teacher could then read the title and create and install the new quiz. Even though the teacher would still need to spend the time reading the book and creating the quiz, it would take a monetary burden off of the classroom teacher and open the doors for more generosity.

Another idea for the future would be a time-saving activity. Since reading chapter books and creating quizzes can be quite time consuming, students could read and create AR quizzes. Only select students in the classroom may be able to accomplish this task independently in the third grade. Even though students have much exposure to the formatting and patterns of these AR quizzes from taking them so often, this does not necessarily mean they would be ready to write a quiz on their own.

These students would need training in how to write appropriate questions with a correct answer and three incorrect but reasonable answer choices. They would need direction in how to choose main ideas not small details of the text to be used as questions. A workshop learning time would be very beneficial for this purpose and could be held during study hall or even before or after school. This would allow time to learn these skills that would include a time to compare and contrast appropriate versus inappropriate questions and answer choices. After students created the new quizzes, the teacher would need to peruse the book's text, check the questions and answer choices, and make any changes before adding the quiz to the AR software.

Perhaps several students could be trained on how to navigate the AR software necessary to install these quizzes into the computer system. This would require proper 
teacher supervision in the classroom as students would be have access to a private area of the software intended for teacher use. These activities could be a large time-saver for the teacher and a challenging reading and writing extension activity for higher-achieving reading students.

\section{Potential Application}

At the time of this project, the school librarian stated that she knows of no other teacher in the building who had ever created and installed his or her own AR quizzes into the software. After sending a note to all the teachers alerting them to the new AR quizzes available, several teachers expressed their need to do the same project with a group of books in their own classroom libraries. This lead to a conversation with a resource room teacher who stated she also created several AR quizzes for her students since our school library did not offer an abundance of lower level books from which her students could choose.

Perhaps in the coming school year, a short workshop during planning times or after-school could be given in order to introduce Maplewood's teachers to the benefits of creating quizzes for their own AR classroom libraries as well as the ease of installing quizzes into the AR software. Several teachers seem to want to take this step, but they have expressed that their lack of knowledge installing the quizzes into the AR software is holding them back. There is hope the knowledge that came from this project can be shared with other Maplewood teachers formally or informally so Maplewood's students can enjoy an even greater variety of and easy access to literature in their desire to read for enjoyment. 


\section{REFERENCES}

Accelerated Reader Program Manual (n.d.). Renaissance Learning.

Allen, J., Shockley, B., \& Baumann, J. (1995). Gathering 'round the kitchen table: Teacher inquiry in the NRRC School Research Consortium. The Reading Teacher, $48(6), 526-529$.

Allington, R.L. (2006). What really matters for struggling readers: Designing researchbased programs $\left(2^{\text {nd }}\right.$ ed.). Boston: Allyn \& Bacon.

Baker, L. (2000). Building the word-level foundation for engaged reading. In L. Baker, M.J. Dreher, \& J.T. Guthrie (Eds.), Engaging young readers: Promoting achievement and motivation (pp. 17-42). New York: Guilford.

Baumann, E. (2009). Education: Before the fall [Professor's Notes]. Cedarville, Ohio: Cedarville University: History and Philosophy of Education.

Biggers, D. (2001). The argument against Accelerated Reader. Journal of Adolescent \& Adult Literacy, 45(1), 72.

Bryan, G., Fawson, P.C., \& Reutzel, D.R. (2003). Sustained silent reading: Exploring the value of literature discussion with three non-engaged readers. Reading Research and Instruction, 43(1), 47-73.

Chapman, J.W. (1998). Learning disabled children's self-concepts. Review of Educational Research, 58, 347-371.

Chapman, J.W. \& Tunmer, W.E. (1995). Development of young children's reading selfconcepts: An examination of emerging subcomponents and their relation with reading achievement. Journal of Educational Psychology, 87, 154-167.

Chapman, J.W. \& Tunmer, W.E. (1997). A longitudinal study of beginning reading achievement and reading self-concept. British Journal of Educational Psychology, $67,279-291$.

Cunningham, A., \& Stanovich, K. (1991). Tracking the unique effects of print exposure in children: Associations with vocabulary, general knowledge, and spelling. Journal of Education Psychology, 83, 264-274.

Cunningham, A., \& Stanovich, K. (1997). Early reading acquisition and its relation to reading experience and ability 10 years later. Developmental Psychology, 33(6), 934.

Dahl, Roald (1964). Charlie and the chocolate factory. Alfred A. Knopf, Inc. 
Davidson, J. \& Koppenhaver, D. (1993). Adolescent literacy: What works and why. New York: Garland.

Donahue, P., Voelkl, K., Campbell, J., \& Mazzeo, J. (1998). NAEP 1998 reading report card for the nation and the states [Online]. Washington, D.C.: U.S. Department of Education, National Center for Educational Statistics. Available: nces.ed.gov/nationsreportcard/pubs/main1998.

Echols, L., West, R., Stanovich, K., \& Zehr, K. (1996). Using children's literacy activities to predict growth in verbal cognition skills: A longitudinal investigation. Journal of Education Psychology, 88, 296-304.

Florida Center for Reading Research (2006). Accelerated Reader. Retrieved May 15, 2009, from http://www.fcrr.org/fcrrreports/pdf/Accelerated_Reader.pdf.

Gambrell, L. \& Morrow, L. (1996). Creating motivation in contexts for literacy learning. In P. Afflerbach, L. Baker, \& P. Reinking (Eds.), The engagement of perspective for reading (pp. 115-136). Hillsdale, NJ: Lawrence Erlbaum.

Gottfried, A. (1990). Academic intrinsic motivation in young elementary school children. Journal of Educational Psychology, 82(3), 525-538.

Greer, J. (2003). POINT. Teacher Librarian, 30(4), 32.

Griffiths, Y. \& Snowling, M. (2002). Predictors of exception word and nonword reading in dyslexic children: The severity hypothesis. Journal of Education Psychology, 94, $34-43$.

Guthrie, J. \& Knowles, K. (2001). Promoting reading motivation. In L. Verhoeven \& C.E. Snow (Eds.), Literacy and motivation: Reading engagement in individuals and groups (pp. 159-176). Mahwah, NJ: Erlbaum.

Guthrie, J. \& Wigfield, A. (1997). Reading engagement: A rationale for theory and teaching. In J.T. Guthrie \& A. Wigfield (Eds.), Reading engagement: Motivating readers through integrated instruction (pp.1-12). Newark, DE: International Reading Association.

Guthrie, J., Wigfield, A., Metsala, J., \& Cox, K. (1999). Motivational and cognitive predictors of text comprehension and reading amount. Scientific Studies of Reading, 3(3), 231-256.

Hautman, P. (1996). Mr. Was. New York: Simon \& Schuster Books for Young Readers.

Institute for Academic Excellence (1998). How Accelerated Reader quizzes are designed. Madison, WI: Institute for Academic Excellence. 
Ivey, G. \& Broaddus, K. (2001). "Just plain reading": A survey of what makes students Want to read in middle school classrooms. Reading Research Quarterly, 36, 350-377.

Kelley, M. \& Clausen-Grace, N. (2006). The sustained silent reading makeover that transformed readers. Reading Teacher, 60(2), 148-156.

Krashen, S. (2004). False claims about literacy development. Educational Leadership, 61(6), 18-21.

Krashen, S. (2004). The Power of Reading Insights from the Research, $2^{\text {nd }}$ ed. Portsmouth, NH: Heinemann.

Krashen, S. (2009). Anything but reading. Knowledge Quest, 37(5), 18-25.

Kurth, R. \& Kurth, L. (1987). The use of time in formal reading instruction in elementary schools. Paper presented at the annual meeting of the American Educational Research Association, Washington D.C.

LaBrant, L. (1958). An evaluation of free reading. Research in the Three R's. C. Hunnicutt and W. Iverson (Eds.), New York: Harper, 154-161.

Lepola, J., Posliparta, E., Laakkonene, E., \& Niemi, P. (2005). Development of and relationship between phonological and motivational processes and naming speed in predicting word recognition in Grade 1. Scientific Studies of Reading, 9, 367-399.

Lepola, J., Vauras, J. \& Maki, H. (2000). Gender differences in the development of academic self-concept of attainment from the $2^{\text {nd }}$ to the $5^{\text {th }}$ grade: Relations with achievement and perceived motivational orientation. The Journal of Hellenic Psychological Society, 7, 3-21.

Manning, G.L., \& Manning, M. (1984). What models of recreational reading make a difference. Reading World, 23, 375-380.

McQuillan, J. (1998). The literacy crisis: False claims, real solutions. Portsmouth, NH: Heinemann.

Morgan, P., \& Fuchs, D. (2007). Is there a bidirectional relationship between children's reading skills and reading motivation?. Exceptional Children, 73(2), 165-183.

Morgan, P., Fuchs, D., Compton, D., Cordray, D., \& Fuchs, L. (n.d.). Does early reading failure decrease children's reading motivation? Journal of Learning Disabilities.

National Institute of Child Health and Human Development (NICHHD), (2000). Report of the National Reading Panel: Teaching students to read. Washington, DC. 
Nolen, S.B. (2001). Constructing literacy in the kindergarten: Task structure, collaboration and motivation. Cognition and Instruction, 19, 95-142.

Nolen, S.B. (2007). Young children's motivation to read and write: Development in social contexts. Cognition \& Instruction, 25(2), 219-270.

Oldfather, P. (1993). What students say about motivating experiences in a whole language classroom . The Reading Teacher, 46, 672-681.

Oldfather, P. (2002). Learning from students about overcoming motivation problems in literacy learning: A cross-study analysis and synthesis. Reading \& Writing Quarterly: Overcoming Learning Difficulties, 18(4), 343-352.

Overbaugh, R. \& Schultz, L. (n.d.) Bloom's taxonomy. Old Dominion University. Retrieved July 28, 2009, from http://www.odu.edu/educ/roverbau/Bloom/blooms_taxonomy.htm.

Pajares. F. (2003). Self-efficacy beliefs, motivation, and achievement in writing: A review of the literature. Reading \& Writing Quarterly, 19(2), 139-158.

Paul, T.D. (1995). Improving reading growth through the application of Vygotskian principles and advanced computer technology to literature-based reading programs. Paper presented at International School Psychology Colloquium, Dundee, Scotland.

Paul, T.D. (1996). A cybernetic approach to motivation and improvement of human systems, with an emphasis on schools, technology, and literacy. Paper presented at the National Reading Research Center conference "Literacy and Technology for the $21^{\text {st }}$ Century," Atlanta, Georgia.

Pavonetti, L., Brimmer, K., \& Cipielewski, J. (2002). Accelerated Reader: What are the lasting effects on the reading habits of middle school students exposed to Accelerated Reader in elementary grades?. Journal of Adolescent \& Adult Literacy, 46(4), 300.

Pekrun, R., Goetz, T., Titz, W., \& Perry, R.P. (2002). Academic emotions in students' self-regulated learning and achievement: A program of qualitative and quantitative research. Educational Psychologist, 37(2), 91-105.

Pilgreen, J. (2000). The SSR handbook: How to organize and manage a sustained silent. reading program. Portsmouth, NH: Heinemann.

Pitcher, S., Albright, L., DeLaney, C., Walker, N., Seunarinesingh, K., Mogge, S., et al. (2007). Assessing adolescents' motivation to read. Journal of Adolescent \& Adult Literacy, 50(5), 378-396.

Pressley, M. (2002). Reading instruction that works: The case for balanced teaching $\left(2^{\text {nd }}\right.$ ed.). New York: Guilford. 
Quirk, M. \& Schwanenflugel, P. (2004). Do supplemental remedial reading programs address the motivational issues of struggling readers? An analysis of five popular programs. Reading Research and Instruction, 43, 1-19.

Rapp, D., \& van den Broek, P. (2005). Dynamic text comprehension. Current Directions in Psychological Science, 14(5), 276-279.

Renaissance Learning (2009). Accelerated Reader. Retrieved May 15, 2009, from http://www.renlearn.com/ar/.

Reutzel, D., Fawson, P., \& Smith, J. (2008). Reconsidering silent sustained reading: An exploratory study of scaffolded silent reading. Journal of Educational Research, 102(1), 37-50.

Schunk, D.H. (1994). Self-regulation of self-efficacy and attributions in academic settings. In D.H. Schunk \& B.J. Zimmerman (Eds.), Self-regulation of learning and performance: Issues and educational applications. Hillsdale, NJ: Lawrence Erlbaum Associates.

Schunk, D.H. \& Rice, J.M. (1993). Strategy fading and progress feedback: Effects on self-efficacy and comprehension among students receiving remedial reading services. Journal of Special Education, 27, 257-276.

Shapiro, E. \& Cole, C. (1994). Behavior change in the classroom: Self-management interventions. New York \& London: Guilford Press.

Stahl, S. (2004). What do we know about fluency? In P. McCardle \& V. Chhabra (Eds.), The voice of evidence in reading research (pp. 187-211). Baltimore: Paul H. Brookes.

STAR Program Manual (n.d.). Renaissance Learning.

Strommen, L.T. \& Mates, B.F. (2004). Learning to love reading: Interviews with older children and teens. Journal of Adolescent \& Adult Literacy, 48, 188-200.

Student Progress Monitoring (2007). Review of Progress Monitoring Tools. Retrieved May 15, 2009, from http://www.studentprogress.org/chart/chart.asp.

Sweet, A., Ng, M., \& Guthrie, J. (1998). Teacher perceptions and student reading motivation. Journal of Educational Psychology, 90(2), 210.

Thorkildsen, T.A. (2002). Literacy as a lifestyle: Negotiating the curriculum to facilitate motivation. Reading \& Writing Quarterly, 18(4), 321-341. 
Thorkildsen, T.A., Nicholls, J.G., Bates, A., Brankis, N., \& DeBolt, T. (2002).

Motivation and the struggle to learn: Responding to fractured experience. Boston: Allyn \& Bacon.

Topping, K. \& Lindsay, G. (1992). Paired reading: A review of the literature. Research Papers in Education, 7, 199-246.

Topping, K., \& Paul, T. (1999). Computer-assisted assessment of practice at reading: A large scale survey using accelerated reader data. Reading \& Writing Quarterly, 15(3), 213-231.

Vanwagenen, M., Williams, R., \& McLaughlin, T. (1994). Use of assisted reading to improve reading rate, word accuracy, and comprehension with ESL Spanish speaking students. Perceptual and Motor Skills, 79, 227-230.

Vollands, S., Topping, K., \& Evans, R. (1999). Computerized self-assessment of reading comprehension with the Accelerated Reader: Action research. Reading \& Writing Quarterly, 15(3), 197-211

Vygotsky, L. (1978). Mind in society: The development of higher psychological processes. M. Cole, V. John-Steiner, S. Scribner, \& E. Souberman (Eds.). Cambridge, MA: MIT Press.

Walker, B.J. (2003). The cultivation of student self-efficacy in reading and writing. Reading \& Writing Quarterly, 19(2), 173-187.

Wang, J. \& Guthrie, J. (2004). Modeling the effects of intrinsic motivation, extrinsic motivation, amount of reading, and past reading achievement on text comprehension between U.S. and Chinese students. Reading Research Quarterly, 39, 162-184.

Wigfield, A. \& Guthrie, J. (1997). Relations of children's motivation for reading to the amount of breadth of their reading. Journal of Educational Psychology, 89, 420-432. 
APPENDIX

Appendix A: Samples of Self-Created Accelerated Reader Quizzes 


\section{APPENDIX A \\ SAMPLE OF SELF-CREATED ACCELERATED READER QUIZZES}

The correct answer choice is always listed first.

Book Title: Colorful Chameleons

Reading Level: 3.0

Self-Created Quiz

1. A chameleon is a kind of --.
a. Lizard
b. Insect
c. Snake
d. Dragon

2. Where do chameleons spend most of their time?
a. In the trees
b. In the ocean
c. On the beach
d. In the grass

3. Chameleons are amazing because they can --.
a. Change colors
b. Run quickly
c. Live for years
d. Go for days without eating

4. Where do most chameleons live?
a. Africa
b. South America
c. Asia
d. North America

5. Where are chameleons most happy?
a. In their special places in the wild
b. In the pet store
c. In homes as pets
d. In water 
Book Title: Case of the Sneaker Sneak

Reading Level: 2.8

Author: James Preller

Self-Created Quiz

Point Value: 1.0

1. Why would you want Biggs on your football team?
a. He was the biggest and best.
b. He scared the other team.
c. He jumped higher than anybody else.
d. He cheated to win.

2. What was the Turkey Lurkey?
a. A dance Mrs. Gleason taught her students
b. A football game
c. An art activity
d. The name of the mystery Jigsaw solved

3. Why did they call the football game the Turkey Bowl?

a. It was played on Thanksgiving Day.

b. It was played on Christmas Day.

c. It was played by a turkey farm.

d. The players loved turkey.

4. How did Jigsaw know the other kids stole the sneakers?

a. They all had other plans after school instead of going to the football game.

b. They gave the sneakers back.

c. Their moms told on them.

d. They were caught with the sneakers.

5. Who found the sneakers?
a. Mr. Copabianco
b. Mila
c. Jigsaw
d. Biggs 
Book Title: Emperor Penguins

Reading Level: 2.9

Self-Created Quiz

1. Penguins are unlike most birds because -- .
a. They do not fly.
b. They do not have beaks.
c. They live outside.
d. They make nests.

2. What can penguins do faster than any other bird?
a. Swim
b. Fly
c. Eat
d. Run

3. What is an example of penguins using teamwork?
a. Fathers huddling together to stay warm.
b. Swimming quickly through the water.
c. Using their beaks and claws to climb.
d. Mom taking a long walk to the sea.

4. Why aren't there penguins in Ohio?
a. Penguins only live south of the equator.
b. Penguins only live in Australia.
c. Penguins only live in Alaska.
d. Penguins only live South America.

5. What does the father do to care for the penguin eggs?
a. Put the egg under its belly
b. Sit on the egg
c. Bury the egg
d. Hide the egg 
Book Title: Stanley and the Magic Lamp

Author: Jeff Brown

Reading Level: 3.7

Point Value: 1.0

Self-Created Quiz

1. Why did Prince Haraz have to do 2,000 years of lamp duty?

a. He was playing too many jokes on people.

b. He stole from the King.

c. It was his turn.

d. He wanted to do it.

2. How did Stanley and Arthur feel when the genie appeared in their room?
a. Terrified
b. Glad
c. Embarrassed
d. Thrilled

3. How could you use Askit Basket?
a. To do your homework
b. To clean your room
c. To babysit your little sitter
d. To make you snacks

4. Why did Stanley get a liophant?

a. He changed his wish in the middle of his wish.

b. He wanted a liophant.

c. The genie chose it for him.

d. Stanley's parents always wanted one.

5. What words describe Tom McRude the tennis player?
a. Nasty and rude
b. Helpful and kind
c. A good teacher
d. Messy and strange

6. What did Stanley's mom wish for?
a. To know what it feels like to be famous
b. To know what it feels like to be rich
c. To be able to play tennis better then Tom McRude
d. To live forever 
7. How did Arthur use his mighty strength?
a. He rescued people from a robbery.
b. He helped his parents move furniture.
c. He stopped an airplane in the air.
d. He picked up a cruise ship.

8. Why was the genie embarrassed?

a. He had a training lamp.

b. He couldn't fly as fast as the boys.

c. He lost his magic powers.

d. He fell down.

9. What wish was the hardest to say goodbye to?
a. Liophant
b. Mom being famous
c. Being able to fly
d. Being strong

10. Why was Stanley's father so proud of Stanley's last wish?
a. Stanley was being kind and generous.
b. Stanley wished for a present for his dad.
c. Stanley didn't use his last wish.
d. Stanley wished for 100 more wishes. 
Book Title: The Curse of Snake Island

Author: Brian James

Reading Level: 3.2

Self-Created Quiz

Point Value: 1.0

1. Why were the kids going to walk across the deck of fish guts?

a. To show they were ready to be real pirates

b. For a game

c. To show they were not scared of fish

d. To get smelly

2. -- was in charge of the pirate school.

a. Rotten Tooth

b. Aaron

c. Vicky

d. Sea Rat

3. At the beginning, what were the kids really learning on the ship?

a. How to clean

b. How to be brave pirates

c. How to be heroes

d. How to look out for other pirates

4. What words best describe Rotten Tooth?

a. Mean and smelly

b. Smelly and happy

c. Helpful and kind

d. Friendly and happy

5. What did Captain Stinky Beard think when he found the kids in his office?

a. They were telling him the truth about the sleepover.

b. They were there is steal his map.

c. They were messing up his office.

d. They wanted to go home.

6. What did Clegg say would happen if you looked a snake in the eyes?

a. You would become a snake.

b. The snake would bite you.

c. You would turn green.

d. The snake would squeeze you. 
7. How did Inna feel about snakes?
a. Hated them
b. Loved them
c. Wanted some as pets
d. Wanted to see some

8. How did the kids escaped from the snakes in the cave?
a. The snakes turned into people.
b. The snakes slithered away.
c. The kids scared the snakes.
d. The kids ran away.

9. Who was the only person NOT happy at the end?
a. Rotten Tooth
b. Captain Stinky Beard
c. Inna
d. The old woman

10. What kind of selection was this?
a. Pretend and could never happen
b. Pretend but could happen
c. True
d. A play 
Book Title: Tink, North of Never Land

Reading Level: 3.7

Self-Created Quiz

1. How did Terrance feel about Tink?
a. Liked her a lot
b. Did not like her
c. Wished she would leave him alone
d. Thought she was very funny

2. Why did they use fairy dust?
a. To make things fly
b. To disappear
c. To shrink things
d. To make things bigger

3. How did Tink feel when she saw Terrance with other girls?
a. Jealous
b. Happy
c. Excited
d. Tired

4. What did Tink wish she would not have said to Terrance?
a. "Leave me alone!"
b. "You are a great friend."
c. "Help me with the compass."
d. "Did you use fairy dust?"

5. Tink was in danger because she landed in a -- home.
a. Possum's
b. Bird's
c. Tiger's
d. Bear's

6. Who did Tink play with on her trip to the Northern Shore?
a. Peter Pan
b. The possums
c. The Queen
d. The mermaid

Author: Kiki Thorpe

Point Value: 1.0 
7. What did Tink get from her trip to the Northern Shore?
a. Nothing
b. Pixie dust
c. Treasures
d. A new dress

8. Why were all Tink's friends at her house when she returned from the Northern Shore?

a. They were worried about her.

b. They wanted to see her pots and pans.

c. They were going to have a party.

d. They were mad at her.

9. What did Tink give Terrance to say she was sorry?
a. A bowl
b. A compass
c. Pixie dust
d. Food

10. What lesson is learned from this story?

a. Be careful what you say to your friends.

b. Don't use a compass.

c. You need a present to say that you are sorry.

d. Don't go to the Northern Shore. 
Book Title: Night of the Full Moon

Reading Level: 4.2

Self-Created Quiz
Author: Gloria Whelan

Point Value: 1.0

1. What did Fawn and Libby have in common?

a. They both had a new baby in the family.

b. They both were Indians.

c. They both loved the moon.

d. They were allowed to visit each other whenever they wanted.

2. What was to happen the night of the full moon?

a. An Indian celebration for Fawn's new brother

b. A party for Libby

c. A meeting to talk about the Indians moving

d. A sleepover for Libby and Fawn

3. What did Papa warn the Indians about?

a. Soldiers taking the Indians away

b. Bears attacking

c. Thieves stealing

d. Woods being cut down

4. When Mama was giving birth, why was Papa upset with Libby?

a. She was only caring about herself.

b. She said she didn't want a new baby.

c. She broke the baby's cradle.

d. She yelled at Mama.

5. Why did the soldiers think Libby was an Indian?

a. She was dressed like one.

b. She spoke the Indian's language.

c. She said that she was an Indian.

d. She had an Indian name.

6. Why did Sanatuwa help Libby get home?

a. Libby's family once helped their daughter.

b. He didn't want her around.

c. The other Indians were upset she was there.

d. Libby's father sent a letter. 
7. Why didn't the soldier stop them from escaping in the night?

a. He believed they should be as free as he was.

b. He was not working at the time.

c. He did not see them in the dark.

d. He chased them but couldn't keep up.

8. What did Mama and Papa think happened to Libby?

a. She was lost in the woods.

b. She was captured by Indians.

c. She was eaten by a wild animal.

d. She visited Fawn.

9. How did Fawn and Libby feel at the end?
a. Sad
b. Excited
c. Tired
d. Surprised

10. What lesson could be learned from this story?

a. Always tell your parents where you are going.

b. Never pick berries.

c. A full moon is dangerous.

d. Practice makes perfect. 
Book Title: Willow's Underwater World

Reading Level: 4.8

Author: Kay Woodward

Self-Created Quiz

1. What did Willow find strange at the beginning of the story?

a. The river water was rising when there hadn't been any rain.

b. The river water was sinking even though there had been rain.

c. The river was turning green.

d. The river was moving too swiftly.

2. Iris and Cornflower both felt -- when they saw something strange in the water.
a. Terrified
b. Thrilled
c. Mad
d. Calm

3. What was the Flower Fairy Law?

a. Fairies should stay out of the sight of humans.

b. Humans are fairies' friends.

c. Humans are smarter than fairies.

d. Fairies can trust human children.

4. What were the children doing?

a. Making a dam

b. Fishing

c. Swimming

d. Jumping in the water

5. Why did the children run away without taking down the dam first?

a. They didn't want their uncle to see what they had done.

b. None of the rocks would move.

c. They wanted to leave the dam there.

d. They forgot to take it down.

6. Why didn't the fairy just move the rocks?

a. They were much too small and weak.

b. They wanted to keep the dam.

c. The Kingcup and Queen would not let them.

d. The children would see them. 
7. "When he realized how rude he had been, his cheeks turned as red as his outfit." What does this mean?
a. He was embarrassed.
b. He was being silly.
c. He was scared.
d. He was showing off.

8. The monster fish was really --.
a. Very kind
b. An octopus
c. Dangerous
d. Scared

9. What word describes how the dam was moved?
a. Teamwork
b. Muscles
c. Humans
d. Fish

10. What happened to the magic beads?
a. They turned into flowers.
b. They were lost.
c. Mr. Pike took them with him.
d. Willow kept them. 
Book Title: Superhero or Super Thief

Reading Level: 4.0

Self-Created Quiz

1. What superhero powers did Max have?
a. Could fly
b. Super strength
c. Super speed
d. All of the above

2. What caused Max to get weak?
a. Math
b. Kryptonite
c. Singing
d. Being around his sister

3. What happened after the President viewed the security tapes?

a. He blamed Max for the robberies.

b. He asked Max to help him solve the robberies.

c. He put Max in jail.

d. He held a lunch in Max's honor.

4. What was stolen?

a. The Hope Diamond

b. The President's desk

c. The Washington Monument

d. The Declaration of Independence

5. How did Max feel when the news said that he was the thief?
a. Like crying
b. So angry
c. Embarrassed
d. Guilty

6. Who helped Max solve the robberies?
a. Tortoise Man
b. Mrs. Tortoise Man
c. Ethelrod
d. Max's dad

Author: Dan Greenburg

Point Value: 2.0 
7. When Max was in jail, why did he want to be home for supper?

a. They were having pepperoni pizza, his favorite.

b. Mom and dad were so worried.

c. The President was coming over for dinner.

d. Tortoise Man would be there.

8. What was Ethelrod's problem?

a. He was always late.

b. He was always early.

c. He was getting too old to be a superhero.

d. He hated math.

9. What word describes Mr. Boogerfinger, Max's lawyer?
a. Worthless
b. Helpful
c. Smart
d. Mean

10. The President gave Max --.

a. The Congressional Medal of Honor

b. A blue ribbon

c. A gold star

d. A gift certificate 
Book Title: The Fairy Realm

Reading Level: 4.3

Self-Created Quiz

1. This selection is --.
a. Fantasy fiction
b. Realistic fiction
c. Non-fiction
d. A mystery

2. Why was Grandmother going to move with Jessica and her mom?

a. Grandmother hurt herself tripping over a cat.

b. Grandmother's house was old.

c. Grandmother's house was haunted.

d. Grandmother hurt herself working in the garden.

3. Why couldn't Grandmother remember The Realm?

a. Her bracelet was lost.

b. Her memory was getting bad.

c. The Realm was just a bad dream.

d. The cat cast a spell on her.

4. How did young Jessica feel when she first was in The Realm?

a. Terrified

b. Excited

c. Embarrassed

d. Amazed

5. What word best describes Valda?
a. Evil
b. Kind
c. Smart
d. Annoying

6. Young Jessica was -- when she wore Grandmother's cloak?
a. Invisible
b. Warm
c. Itchy
d. Scared

Author: Emily Rodda

Point Value: 2.0 
7. How did Jessica get back to Grandmother's house?
a. She tricked Valda.
b. She used magic dust.
c. She opened The Door.
d. She used a secret passageway.

8. In the end, who was the new Queen?
a. Helena
b. Jessica
c. Valda
d. Giff

9. What did Jessica receive from Helena?
a. A heart necklace
b. A charm bracelet
c. A horse
d. A new dress

10. Grandmother decided to live --.
a. In her own house
b. In The Realm
c. At Jessica and her mom's house
d. In the secret garden 
